\title{
Teaching of Oral College English: Design and Evaluation --- Exploration of Educational Reform in College English in Capital University of Physical Education and Sports
}

\author{
Youming Wang \\ Capital University of Physical Education and Sports, Beijing 100191, China \\ E-mail: wangyouming@cipe.edu.cn
}

Received: June 22, 2011

Accepted: July 20, $2011 \quad$ Published: April 1, 2012

doi:10.5539/ijel.v2n2p33

URL: http://dx.doi.org/10.5539/ijel.v2n2p33

Research achievement of "Study on Strategy and Evaluation of Oral College English Teaching", an education and teaching reform project in colleges and universities in Beijing.

\begin{abstract}
This paper briefly analyzes issues existing in oral English teaching in physical institutes and puts forwards teaching design in oral activities and several evaluation methods for oral competence of students. The aim is to offer some new trains of thought for foreign language teaching reform in physical institutes.
\end{abstract}

Keywords: Oral activities, Teaching design, Evaluation measures

\section{Introduction}

With accelerated internationalization step of China, all walks of life have proposed higher demand on foreign language competence of graduates. According to new requirements of the college English teaching, the author has made reform on college English teaching in physical institutes, enlarged proportion of listening and speaking and confirmed setting of the goal. In the past two years, the subject group has tracked reform practice of oral English teaching in the students of department of physical education who entered the institute in 2005 . The author set up an initial teaching framework from the design of the classroom to the method of evaluation. Here, the author summarizes the experience as below to serve as a modest spur.

\section{Issues existing in oral English and reasons}

In the oral English classroom, a large number of students have no idea what to say in addition to "How are you?", "How old are you?, "What's your name?" and so on. As a result, the following phenomena emerge: (1) silence; (2) some students are reluctant to participate in activities; (3) group activities are under control of some individual students; (4) there is no reaction to any question asked, and mother tongue is used to replace the target language English; (5) there are some students in the classroom who are "forgotten" (Lv Yongming, 2004); (6) sleeping and playing with the mobile phone, etc. At the initial stage of college English teaching, the author conducted a questionnaire survey on learning strategy, classroom performance and self evaluation of 46 students from two classes in the department of physical education who entered the institute in 2005. The survey indicates that, the students have strong learning desire (37\%); students hold a positive attitude towards teachers' asking questions (50\%), but various problems happen in their speech: disfluency (59\%), mixing of Chinese and English (15\%), borrowing mother tongue and even having no idea what is said (11\%); the ability of students to recite and read aloud is better than to have a conversation (students may feel difficult in reciting an English text at the beginning of their entering the institute, but they are able to form a good habit of reciting half a year later), and there are $41.3 \%$ students who can recite the content stipulated and there are $39.13 \%$ students who can read aloud; in a conversation, there are $17 \%$ students who are quite positive and $21 \%$ students who are common. Usually, some students don't speak, and they just sleep and play with the mobile phone. During the survey, it is found that students have the strong will to improve their oral English level. However, as a result of such elements of bad foundation, bad learning habits and ambiguous knowledge in the urgency to improve the oral English competence, oral English falls in the "strange circle" of "not speaking well and reluctant to speak". In terms of teaching, the teaching method is inappropriate and teaching attention is not enough from the subjective 
perspective and the class hours are insufficient from the objective perspective. As a result, "instructing" often replaces "speaking" in oral English teaching and only key objects are paid attention to. Besides, definite requirements and incentive target and means are lacking in evaluation, so it is difficult for oral English teaching to achieve an anticipated effect.

\section{Strategies of Oral English Teaching}

Students from the department of sports have the desire and interest in learning English, but this often does not last long. Their instant memory is strong in the process of learning and their abstract memory is bad. They master a small number of vocabulary and seldom review (since their professional training occupies most of the time), which causes students to be passive in oral English activities, with low enthusiasm, and thus they are often "forgotten". With view to these situations, we can build abundant language environment to enable them to appreciate the joy of "participation by all".

\subsection{To build an environment of language and to mobilize students to open their mouth}

In teaching, we can design an oral English activity that is centered by recitation to enable students to have enough opportunities to listen, read and recite. Recitation means language input. When language input achieves a certain amount, it is gradually converted to speaking, namely, language output. The specific practice is as follows: 1) recitation; 2) repetition; 3) talking about pictures, group discussion and statement; 4) conversation and give presentations according to picture conversations. We can offer demonstration of recitation to students with bad foundation and help keep them from becoming a "forgotten group"; 5) to demonstrate meaning of vocabulary with pictures to realize visible, touchable and tasteable and to give full play to the multiple sense organs of students; 6 ) to offer incentives of competition since students of sports institutes are active and love to excel others. With regard to this characteristics, we can bring competitive exercises (exercise of vocabulary with different groups) into teaching, mobilize students' desire of self-performance and firmly attract students to the magnetic field of teaching. in the meantime, we can alternate such diversified teaching methods of group conversations and singing so as to continuously offer students with opportunities of performance and cultivate step by step their interest in English.

\subsection{To encourage leading and to establish confidence of students}

It is discovered in teaching that, a small number of students are articulated in answering questions and speak fluently, whereas most students are "introverted" in their performance and do not dare to show themselves. The reason for this contrast is that they are lacking in self-confidence and have bad English foundation. When using the communicative approach, there is no need for teachers to criticize students' errors in the process of learning since errors are just natural in the process of learning. Instead, they may help students to overcome their psychological obstacles and defeat students' emotion of being afraid of difficulty in "speaking", give more incentives to them and should not ask students to be one hundred percent accurate. Evaluation of teachers on students has strong orientation effect, so if the evaluation is inappropriate, students may lose confidence. And if the evaluation is appropriate and teachers are able to stimulate students' interest in "speaking", and students' self confidence, then students may transfer from "dare not to speak" to "I would like to speak".

\subsection{To perfect classroom design and improve teaching effect}

In an oral activity, teachers ought to offer an abundant platform to let students get familiar with oral English communication as soon as possible. They may start from saying help and gradually lead students to find out an entry point for an appropriate topic. This topic has to comply with the knowledge and competence level of students in sports institute so as to make them gradually have the desire of communication. After having finished one or two units, teachers may take out one class to specially ask students to talk about their family members, their friends, their classmates and their hobbies and interests, etc, to express their will and to experience the achievement felling of learning English.

Let's take Unit Four in the second volume of "Experiencing English" as an example to illustrate in details course design and teaching procedures. The topic of this unit is purposes of young people in wearing adornment in their daily life.

\begin{tabular}{|l|l|l|l|}
\hline $\begin{array}{l}\text { Teaching } \\
\text { requirement }\end{array}$ & Teaching content & Teaching goal & $\begin{array}{l}\text { Teaching plan: } \\
\text { arrangement of time and } \\
\text { activities }\end{array}$ \\
\hline $\begin{array}{l}\text { Vocabulary and } \\
\text { sentence pattern }\end{array}$ & $\begin{array}{l}\text { Bracelet Ring earrings pin scarf } \\
\text { to protect me }\end{array}$ & $\begin{array}{l}\text { Supplement vocabulary } \\
\text { required }\end{array}$ & $\begin{array}{l}\text { Time: } 15 \text { minutes } \\
\text { Activity pattern: the }\end{array}$ \\
\hline
\end{tabular}




\begin{tabular}{|c|c|c|c|}
\hline & $\begin{array}{l}\text { for fun } \\
\text { it has special powers } \\
\text { Grandmother gave it to me } \\
\text { a lot of sentimental value } \\
\text { Makes me look good } \\
\text { Reminds me of appointments }\end{array}$ & $\begin{array}{l}\text { communication and help } \\
\text { students to make } \\
\text { preparations } \\
\text { conversations }\end{array}$ & $\begin{array}{l}\text { entire class } \\
\text { Classroom organization: } \\
\text { teachers explaining } \\
\text { difficult words and } \\
\text { phrases and then reading } \\
\text { aloud. }\end{array}$ \\
\hline $\begin{array}{l}\text { Background } \\
\text { knowledge }\end{array}$ & $\begin{array}{l}\text { "Lucky charms" or superstitions that } \\
\text { are common where you live. In } \\
\text { Japanese culture, e.g. students taking } \\
\text { exams may carry special pencils or } \\
\text { other items purchased at shrines } \\
\text { devoted to the gods of education. } \\
\text { They hope that these objects will } \\
\text { help them do well on the exams. }\end{array}$ & $\begin{array}{l}\text { To comprehend Chinese } \\
\text { and English cultural } \\
\text { backgrounds in a } \\
\text { particular context }\end{array}$ & $\begin{array}{l}\text { Time: } 5 \text { minutes } \\
\text { Activity pattern: the } \\
\text { entire class } \\
\text { Classroom organization: } \\
\text { teachers explaining and } \\
\text { students discussing }\end{array}$ \\
\hline $\begin{array}{l}\text { Listening, } \\
\text { reading and } \\
\text { simulating, as } \\
\text { well as } \\
\text { memorizing } \\
\text { important words } \\
\text { and sentence } \\
\text { patterns }\end{array}$ & $\begin{array}{l}\text { 1)the name of the accessory and what } \\
\text { it's made of } \\
\text { 2) why to wear the accessory? }\end{array}$ & $\begin{array}{l}\text { Listen to the tape, } \\
\text { simulate, lead students } \\
\text { step by step to record } \\
\text { sentence patterns that } \\
\text { are usually used and to } \\
\text { make preparations for } \\
\text { activities. This sort of } \\
\text { language input is helpful } \\
\text { to improve linguistic } \\
\text { accuracy. }\end{array}$ & $\begin{array}{l}\text { Time: } 15 \text { minutes } \\
\text { Activity pattern: the } \\
\text { entire class } \\
\text { Classroom organization: } \\
\text { playing the tape, leading } \\
\text { students to read aloud } \\
\text { and simulate, and then } \\
\text { examining }\end{array}$ \\
\hline $\begin{array}{l}\text { Exercise to fill in } \\
\text { the blanks of } \\
\text { conversations }\end{array}$ & $\begin{array}{l}\text { Complete the conversations with the } \\
\text { appropriate response. } \\
\text { Claire: That's an interesting ring, } \\
\text { Bridget. } \\
\text { Bridget: Oh, I got this with money } \\
\text { from__ } \\
\text { Claire: Yeah? Is it a real diamond? } \\
\text { Bridget: Mm..hmm. It's } \\
\text { it has___ but } \\
\text { Claire: } \\
\text { reminds_ } \\
\text { Bridget: }\end{array}$ & $\begin{array}{l}\text { Help students to review } \\
\text { vocabulary and sentence } \\
\text { patterns, enter the } \\
\text { situational simulation } \\
\text { environment step by } \\
\text { step, finish pre-test and } \\
\text { reduce anxiety of } \\
\text { students with bad } \\
\text { foundation. }\end{array}$ & $\begin{array}{l}\text { Time: } 20 \text { minutes } \\
\text { Activity pattern: group } \\
\text { (one group with two or } \\
\text { three students) } \\
\text { Classroom organization: } \\
\text { typical conversation for } \\
\text { classroom activities. } \\
\text { Students with better } \\
\text { foundation make } \\
\text { demonstration and offer } \\
\text { timely help to students } \\
\text { with bad foundation so } \\
\text { as to successfully } \\
\text { complete the task }\end{array}$ \\
\hline $\begin{array}{l}\text { Situational } \\
\text { dialogue/ } \\
\text { Statement } \\
\text { pictures }\end{array}$ & $\begin{array}{l}\text { Situation: A football fan, a pop star } \\
\text { lover and a QQ user describe to each } \\
\text { other the different accessories they } \\
\text { wear and explain the resorts for } \\
\text { wearing them. After talking they } \\
\text { have a better understanding of the } \\
\text { things. }\end{array}$ & $\begin{array}{l}\text { Help students to enter a } \\
\text { real language } \\
\text { environment and to } \\
\text { combine vocabulary and } \\
\text { sentence patterns learned } \\
\text { with actual } \\
\text { communication. }\end{array}$ & $\begin{array}{l}\text { Time: } 30 \text { minutes } \\
\text { Activity pattern: one } \\
\text { group with two students } \\
\text { Classroom organization: } \\
\text { encourage students to } \\
\text { experience language } \\
\text { enjoyment with the } \\
\text { sentence patterns they } \\
\text { learn. Grammar or } \\
\text { pronunciation mistakes } \\
\text { are ignored. }\end{array}$ \\
\hline Summary & Vocabulary: the names of the & To help students to & Time: 5 minutes \\
\hline
\end{tabular}




\begin{tabular}{|l|l|l|l|}
\hline & $\begin{array}{l}\text { accessories } \\
\text { Patterns: How to describe the reasons } \\
\text { for wearing them. }\end{array}$ & $\begin{array}{l}\text { conduct oral English } \\
\text { activities after school. }\end{array}$ & $\begin{array}{l}\text { Activity pattern: the } \\
\text { entire class } \\
\text { Classroom organization: } \\
\text { free discussion, analysis } \\
\text { of mistakes and find out } \\
\text { disadvantages in } \\
\text { communication }\end{array}$ \\
\hline
\end{tabular}

\section{Oral English Teaching Evaluation}

The purpose of oral English teaching is to improve students' oral English expression competence and evaluation of oral English teaching is a real reflection of the teaching goal and teaching effect as well as an important means to facilitate teaching.

\subsection{Principles of evaluation on oral English teaching}

\subsubsection{Unification of performance evaluation and teaching goal}

Under the background of grad examination, traditional teaching is centered with all types of examinations and all colleges and universities connect the teaching level and students' learning capacity with passing rate in CET-4 and CET-6, which endows English teaching with the trace of "exam oriented education". Oral English teaching becomes marginalized and oral English performance is as well without it as with it. Without doubt, oral English competence is an important index for the society to measure the English level of students and evaluation of oral English competence is an organic component of the English performance system. The evaluation method is closely connected with teaching and evaluation of teaching and evaluation of learning are integrated with daily teaching, which focuses on developmental evaluation according to foundation of different students and concentrates on accumulative growth and progress of students.

\subsubsection{Combination of dynamic evaluation and static evaluation}

Dynamic evaluation refers to evaluation on students' participation, learning attitude and learning strategy, etc., which encourages students at different levels to "be active" and to experience joy in "speaking". Static evaluation refers to evaluation on accuracy, fluency, pronunciation and intonation of oral English application, which is aimed to enable students to orient themselves and to facilitate them to make efforts at a higher level.

\subsubsection{Unification of language input and language output}

In order to make an effective use of time in the classroom and to achieve unification of language input and language output, teachers should readjust written teaching content and design language points with features of participation, interaction and convenience for evaluation. At the beginning of each class, teachers ought to set up the interactive goal of classroom recitation and role play. For instance, in Vocabulary Task in "Experiencing English", 2 to 4 students have an oral English presentation for one minute according to the vocabulary and sentence patterns of that class they are going to learn, while other students give immediate comments on these 2 to 4 students' advantages and disadvantages. Each oral English class has to provide the opportunity of 2 to 3 times for group activities of 2 students. This sort of activities may enable students to "enjoy higher level emotional experiences related with the predicament and decision making in their daily life".

\subsection{Pattern, standard and content of evaluation on oral English}

\subsubsection{Pattern of evaluation}

Evaluation is the information feedback on oral English teaching, and simultaneously, may facilitate teaching. pattern of evaluation is simple and is convenient to operate and is scientific. The best oral English pattern is to regard a small group as the unit and implementation of daily performance is the appropriate method. Final examination and classroom activity and recitation in a daily class supplement each other and each has their own emphasis, which can form a progression relationship to enable students with bad foundation avoid the emotion of being afraid of difficulties and students with strong learning ability to get encouraged and stimulated. The test time is five minutes or so for each students.

\subsubsection{Standard of evaluation}

Evaluation standard should not break away from the actual level of students, and otherwise, it might affect the enthusiasm of students in learning. Design of test subjects should take into consideration of characteristics and teaching reality in sports institutes and have a definite object in view. Formation and control of the standard is better to be strict and careful and should avoid being too loose and virtual, grasp dialectic relations between 
accuracy and nature and regards as the primary goal encouraging students to open their mouth and to improve their communicative competence.

\subsubsection{Evaluation content and compilation}

Oral English content should include all language points to be tested, and should increase or decrease any language point randomly. Compilation is to test the designated content, and does not involve other content, which does not set up any question that can only be answered by those with professional knowledge or experience. In one word, design and evaluation of test subjects should take into consideration of the actual English level of students in sports institutes.

Evaluation of competence

1) To convert language pattern into linguistic function and to have role play in a simulation context.

2) To recite accurately and fluently the paragraphs in the text learned and to answer questions.

3) To read aloud accurately the worlds, phrases, sentences or texts learned.

\section{Content of examination}

1) Immediate situational dialogue

2) To confirm test contents from textbooks and examine recitation, reading and answering of questions

Principle for compiling test questions

1) Principle of foundation. Setting of the test subject helps students to lay foundation for their pronunciation, grammar and vocabulary.

2) Principle of practicability. Materials selected ought to require students to express themselves with intonation, gesture or facial expression, so as to achieve the purpose of communication.

3) Principle of facilitation. Subject pattern and content should facilitate teaching and facilitate improvement of oral English competence.

\section{Amount of exams}

1) To give topics to complete a dialogue and to give 1 to 3 questions about daily life according to the actual level of students.

2) To recite a short text with approximately 120 words.

3) To read a short text with approximately 150 words.

\section{Scoring methods}

1) To specify a topic to complete a dialogue or to recite this topic with accurate pronunciation and intonation as well as fluency. Two questions should be answered accurately.

2) To specify a topic to complete several dialogues or to recite with this topic with accurate pronunciation and intonation as well as fluency. One relevant question should be answered.

3) To read aloud, with relatively correct pronunciation and intonation, with no questions answered.

4) Unable to complete reading a short text.

\section{An analysis of the effect of Oral English Teaching}

\subsection{Learning effect of students}

Through analysis of oral English activities and final oral test among students from Class One and Class Three of the Physical Education Department who entered the institute in 2005, it was found that students' enthusiasm and attitude had been greatly improved. Those students who were active to recite texts and answer questions accounted for $68 \%$ in the first year and $95 \%$ in the second year. During the two years, from initial language input, namely, recitation and reading aloud, to repetition of texts and situational performance, the overall oral expression capacity of students has been greatly enhanced and the speed of extracting vocabulary is obviously increased. After two terms, students' average oral expression each minute increased by 12.39 words, especially in terms of picture description and conversation. Those students with good foundation obviously grasp more vocabulary in terms of employing the vocabulary and also master larger amount of information in oral express, which is mainly reflected in Vocabulary Task and Listening Task in "Experiencing English". Nevertheless, the third part in each unit of "Experiencing English" is of great difficulty and is difficult to understand. As a result, students are unable to grasp well the polysemy application of words and have difficulty in enriching their oral 
expression content.

\subsection{Teaching effect of teachers}

The teaching syllabus requires that "evaluation of teaching also includes evaluation on teachers, namely evaluation on their teaching process and teaching effect". Through a qualitative and quantitative analysis as well as a summary of teachers' teaching process and teaching effect, we make an effective judgment to facilitate improvement of teaching level. In the process of teaching, we regard students as the subject and enable students to participate in classroom activities and evaluation and make evaluation on teaching goal, teaching content, teaching pattern, teaching method as well as teachers' quality so as to generate a teaching atmosphere of interaction between teachers and students and interaction between students. We design "an evaluation table for English classroom and teachers' teaching method" and conduct a questionnaire survey (76) among students from Class One and Class Three in the Physical Education Department and students from Class One, Class Two and Class Three in the Social Sports Department who entered the institute in 2005. The purpose is to verify whether the classroom oral teaching method of recitation and situational dialogue can enhance the oral communicative competence of students from sports institutes compared with the traditional teaching method that regards teachers as the center of teaching. According to the survey, there are $67 \%$ students who hold a recognition attitude towards classroom oral teaching, $63 \%$ students who approve the teaching pattern of dialogue and recitation, $88 \%$ students who recognize that the teaching content complies with the actual life of students and $57 \%$ students who hold an active attitude towards oral English activities. Through classroom recitation, students' communicative strategy and cross cultural communication competence have been generally enhanced and the number of "the group that is forgotten" reduces.

\section{Conclusion}

The "bottleneck" of oral expression lies in vocabulary and the ability of digest knowledge. The key to grasp more vocabulary is to enlarge the language input of students, since output is impossible without input. Recitation plays an immeasurable role in oral English teaching in sports institutes since students are likely to experience the joy of "blurting out something". Thus, recitation should be regarded as the center of oral English teaching from beginning to end in the process of teaching and everybody should be encouraged to participate in recitation. In practice, it is discovered that the following several problems still need to be further resolved. Although the information amount of students in oral expression has increased, their expression competence is obviously restrained by vocabulary. In the process of teaching, gap between different students becomes more and more obvious, which indicates that teachers haven't made an analysis of attribution for failure among "poverty-stricken students in learning". Dick Allwright describes the classroom activities as "Put "quality of life' first; work primarily to understand language classroom life; involve everybody; work to bring people together." As a practitioner in language activities, teachers should not only present "teaching" to students, but more "guidance", so as to enable students to really be integrated into the classroom and to give full play to their autonomy in learning.

\section{References}

Allwright, D. (2003). Exploratory Practice: Rethinking practitioner research in language teaching. Language Teaching Research, 7(2):113-41.

Krashen S D. (1987). Second Language Acquisition and Second Language Learning. Oxford: Pergamo, 67-80.

Krashen, Stephen D. (1987). Principles and Practice in Second Language Acquisition. Prentice-Hall International.

Ministry of Education . (2007). College English Curriculum Requirements. Higher Education Press.

Stephen D. Brookfield. (2005). The Skillful Teacher --- On Technique, Trust and Responsiveness in the Classroom, translated by Zhou, Xinhong \& Hong, Ning. Zhejiang University Press, 76-96.

Thomas Scovel. (1998). Psycholinguistics. Oxford University Press, 27-45.

Tricia Hedge. (2001). Teaching And Learning In The Language Classroom. Oxford University Press, 271-292.

Wuyi University Foreign Language Office. (2001). Laying Solid Language Foundations and Improving cultural literacy - A Selection of Papers on College English Teaching. Shanghai Foreign Language Education Press, 268-275.

Yang, Lianrui, et al. (2007). Second language acquisition and foreign language teaching in China. Shanghai Foreign Language Education Press, 185-207, 357-359. 
Table 1. Questionnaire of performance in the classroom and self evaluation

\begin{tabular}{|c|c|c|c|c|}
\hline \multirow[t]{2}{*}{$\begin{array}{l}\text { Your participation in the } \\
\text { classroom }\end{array}$} & $\begin{array}{l}\text { Quite strong (7 } \\
\text { students) }\end{array}$ & $\begin{array}{l}\text { Relatively strong } \\
\text { (17 students) }\end{array}$ & $\begin{array}{l}\text { Common } \\
\text { students })\end{array}$ & $\begin{array}{l}\text { Indifferent } \quad(3 \\
\text { students) }\end{array}$ \\
\hline & $15.22 \%$ & $36.96 \%$ & $41.3 \%$ & $6.52 \%$ \\
\hline \multirow[t]{2}{*}{$\begin{array}{l}\text { Your (response) to teachers' } \\
\text { questions }\end{array}$} & $\begin{array}{l}\text { Positive } \\
\text { response (23) }\end{array}$ & Common (13) & Echo (7) & Silent (3) \\
\hline & $50 \%$ & $28.26 \%$ & $15.22 \%$ & $6.52 \%$ \\
\hline \multirow[t]{2}{*}{$\begin{array}{l}\text { Your performance in oral } \\
\text { activities }\end{array}$} & $\begin{array}{l}\text { Always make a } \\
\text { speech (3) }\end{array}$ & Positive speech & $\begin{array}{l}\text { Less speech } \\
(20)\end{array}$ & Forgotten (3) \\
\hline & $6.52 \%$ & $43.48 \%$ & $43.48 \%$ & $6.52 \%$ \\
\hline \multirow[t]{2}{*}{$\begin{array}{l}\text { Your participation in } \\
\text { compiling a conversation }\end{array}$} & $\begin{array}{l}\text { Quite positive } \\
\text { (17) }\end{array}$ & Common (21) & Inactive (4) & $\begin{array}{ll}\text { Reluctant } & \text { to } \\
\text { participate (4) } & \end{array}$ \\
\hline & $36.96 \%$ & $45.64 \%$ & $8.7 \%$ & $8.7 \%$ \\
\hline \multirow{2}{*}{$\begin{array}{l}\text { Your performance } \\
\text { recitation activities in the } \\
\text { classroom }\end{array}$} & $\begin{array}{l}\text { Active } \\
\text { preparation (19) }\end{array}$ & Common (18) & Inactive (6) & Compelled (3) \\
\hline & $41.3 \%$ & $39.13 \%$ & $13.05 \%$ & $6.52 \%$ \\
\hline \multirow[t]{2}{*}{$\begin{array}{l}\text { Your performance in group } \\
\text { activities }\end{array}$} & $\begin{array}{l}\text { Active speech } \\
(20)\end{array}$ & $\begin{array}{l}\text { Wish others to } \\
\text { promote oneself ( } 7 \text { ) }\end{array}$ & Indifferent (14) & $\begin{array}{l}\text { Reluctant to make } \\
\text { a speech (5) }\end{array}$ \\
\hline & $43.4 \%$ & $15.22 \%$ & $30.43 \%$ & $10.87 \%$ \\
\hline \multirow[t]{2}{*}{ Your performance in a speech } & Fluent (7) & $\begin{array}{l}\text { Influent but able to } \\
\text { express (27) }\end{array}$ & $\begin{array}{l}\text { Often speak } \\
\text { Chinese (7) }\end{array}$ & In a confusion (5) \\
\hline & $15.22 \%$ & $58.71 \%$ & $15.22 \%$ & $10.87 \%$ \\
\hline
\end{tabular}


Table 2. Evaluation on teaching method of teachers

\begin{tabular}{|c|c|c|c|c|}
\hline Teaching goal & $\begin{array}{l}\text { Definite and } \\
\text { rational }\end{array}$ & Strong maneuverability & $\begin{array}{l}\text { Corresponding with } \\
\text { course requirement } \\
\text { and students' reality }\end{array}$ & Unsatisfied \\
\hline & $56 \%$ & $27 \%$ & $17 \%$ & $0 \%$ \\
\hline \multirow[t]{2}{*}{$\begin{array}{l}\text { Teaching content in the } \\
\text { classroom }\end{array}$} & $\begin{array}{lr}\text { Close } & \text { to } \\
\text { students' } & \text { life } \\
\text { reality } & \end{array}$ & $\begin{array}{l}\text { Not close to students' life } \\
\text { reality }\end{array}$ & $\begin{array}{l}\text { Break away from } \\
\text { students' reality }\end{array}$ & $\begin{array}{l}\text { Totally have } \\
\text { no interest }\end{array}$ \\
\hline & $88 \%$ & $12 \%$ & $0 \%$ & $0 \%$ \\
\hline \multirow[t]{2}{*}{$\begin{array}{l}\text { Difficulty in classroom } \\
\text { teaching }\end{array}$} & $\begin{array}{l}\text { Exceeding } \\
\text { language } \\
\text { competence }\end{array}$ & Challenging & $\begin{array}{l}\text { Relatively } \\
\text { appropriate }\end{array}$ & Too simple \\
\hline & $6 \%$ & $22 \%$ & $72 \%$ & $0 \%$ \\
\hline \multirow[t]{2}{*}{$\begin{array}{l}\text { Method of classroom } \\
\text { teaching }\end{array}$} & $\begin{array}{l}\text { Language points } \\
\text { and grammar of } \\
\text { the text }\end{array}$ & $\begin{array}{l}\text { Dialogue, recitation and } \\
\text { reading aloud according to } \\
\text { content of classroom } \\
\text { teaching }\end{array}$ & $\begin{array}{l}\text { Automatic reading of } \\
\text { text material }\end{array}$ & \\
\hline & $35 \%$ & $63 \%$ & $2 \%$ & \\
\hline \multirow[t]{2}{*}{$\begin{array}{l}\text { Students taking part in } \\
\text { classroom activities }\end{array}$} & Active & Sometimes active & Seldom active & Silent \\
\hline & $57 \%$ & $37 \%$ & $4 \%$ & $2 \%$ \\
\hline \multirow[t]{2}{*}{$\begin{array}{l}\text { Teaching method of } \\
\text { teachers }\end{array}$} & $\begin{array}{l}\text { Flexible, with } \\
\text { innovation }\end{array}$ & $\begin{array}{l}\text { Accidently } \\
\text { innovation }\end{array}$ & Copy mechanically & Indifferent \\
\hline & $67 \%$ & $27 \%$ & $6 \%$ & $0 \%$ \\
\hline \multirow[t]{2}{*}{$\begin{array}{l}\text { Teachers guiding } \\
\text { classroom activities }\end{array}$} & Often & Sometimes & Seldom & Have no idea \\
\hline & $86 \%$ & $14 \%$ & $0 \%$ & $0 \%$ \\
\hline \multirow[t]{2}{*}{$\begin{array}{l}\text { Effect of teachers' } \\
\text { teaching method on } \\
\text { improvement of } \\
\text { language competence }\end{array}$} & Effective & Common & No obvious effect & Ineffective \\
\hline & $84 \%$ & $12 \%$ & $4 \%$ & $0 \%$ \\
\hline \multirow[t]{2}{*}{ Quality of teachers } & Quite satisfied & Satisfied & Almost satisfied & Unsatisfied \\
\hline & $86 \%$ & $5 \%$ & $2 \%$ & $0 \%$ \\
\hline
\end{tabular}

